Gender and Disorder in Early Modern Seville 


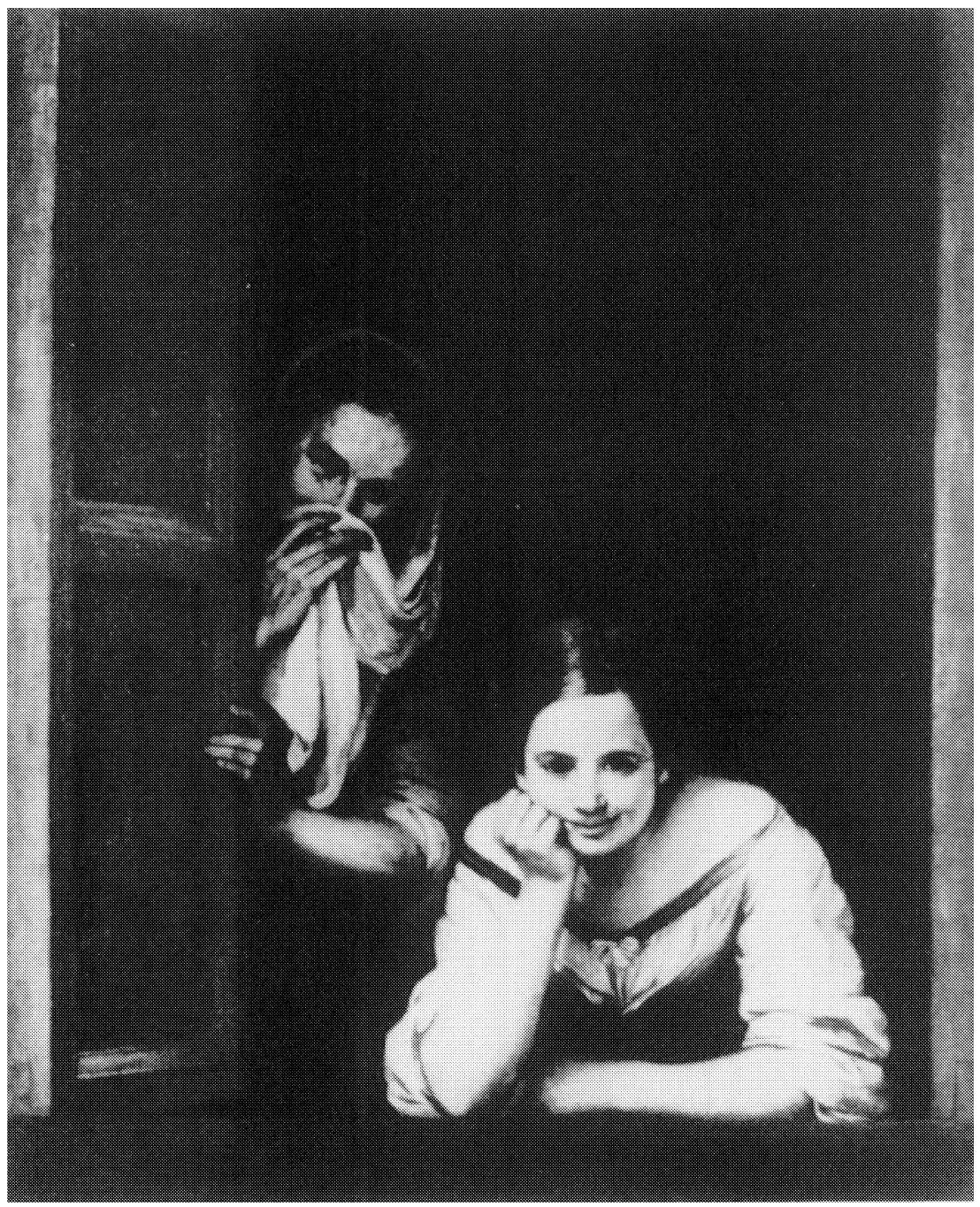

Figure 1. Women at the Window, by Bartolomé Murillo (National Gallery of Art, Washington; Widener Collection). 


\section{Gender and Disorder in Early Modern Seville}

Mary Elizabeth Perry 
Copyright (C) 1990 by Princeton University Press Published by Princeton University Press, 41 William Street, Princeton, New Jersey 08540

In the United Kingdom: Princeton University Press,

Chichester, West Sussex

All Rights Reserved

Library of Congress Cataloging-in-Publication Data

Perry, Mary Elizabeth, 1937-

Gender and disorder in early modern Seville /

Mary Elizabeth Perry.

p. $\mathrm{cm}$.

Includes bibliographical references.

1. Women-Spain-Seville-Social conditions.

2. Sex role-Spain-Seville-History.

3. Women-Spain-Seville-History.

4. Marginality, Social-Spain-Seville-History.

5. Seville (Spain)—Social conditions. I. Title.

HQ1695.S48P47 $1990 \quad$ 90-32784

ISBN 0-691-03143-6 (alk. paper)

ISBN 0-691-00854-X (alk. paper)

Publication of this book has been aided by the Whitney Darrow Fund of Princeton University Press

This book has been composed in Linotron Galliard

Princeton University Press books are printed on acid-free paper, and meet the guidelines for permanence and durability of the Committee on Production Guidelines for Book Longevity of the Council on Library Resources

Printed in the United States of America

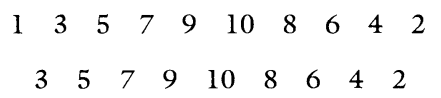

(Pbk.) 
For Antonio Dominguez Ortiz 
